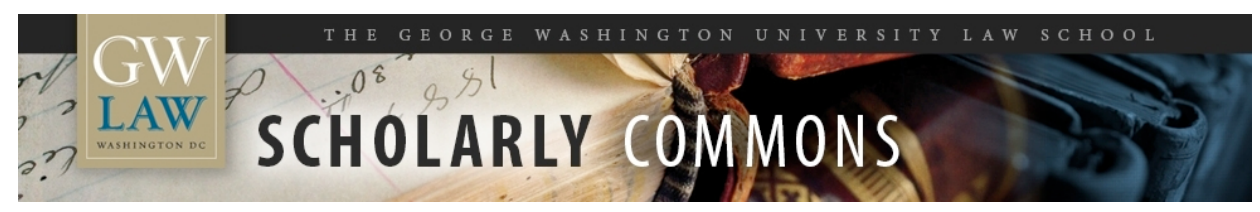

GW Law Faculty Publications \& Other Works

Faculty Scholarship

2010

\title{
The Past, Present, and Future of Energy Regulation
}

Richard J. Pierce Jr

George Washington University Law School, rpierce@law.gwu.edu

Follow this and additional works at: https://scholarship.law.gwu.edu/faculty_publications

Part of the Law Commons

\section{Recommended Citation}

Pierce, Richard J. Jr, "The Past, Present, and Future of Energy Regulation" (2010). GW Law Faculty Publications \& Other Works. 858.

https://scholarship.law.gwu.edu/faculty_publications/858

This Article is brought to you for free and open access by the Faculty Scholarship at Scholarly Commons. It has been accepted for inclusion in GW Law Faculty Publications \& Other Works by an authorized administrator of Scholarly Commons. For more information, please contact spagel@law.gwu.edu. 


\section{The Past, Present, and Future of Energy Regulation \\ Richard J. Pierce, Jr. ${ }^{1}$}

I view my role in this symposium as providing a brief overview of the history of energy regulation in the United States over the last half century, followed by alternative predictions of the future - one optimistic and one pessimistic. I will begin with a description of the history of energy regulation in the hope that we can learn lessons from history that will help us choose a promising approach for the future.

\section{THE PAST}

\section{A. Oil-1960 to 2011}

The US implemented poor fiscal and monetary policies in the 1960s that led to high and rising economy-wide inflation. President Nixon responded to that problem with economy-wide wage and price controls in 1971. ${ }^{2}$ Wage and price controls had devastating effects on the economy that caused them to be the subject of near universal criticism by 1973 . At that time, they were eliminated for all sectors of the economy except oil and petroleum products. ${ }^{3}$

Several factors in addition to economy-wide inflation led to large increases in the price of oil and petroleum products. ${ }^{4}$ First, air quality rules implemented in the $1960 \mathrm{~s}$ induced many electric utilities and industrial consumers to switch from coal to oil or gas, thereby increasing demand for oil. Second, the US position on the 1973 Arab-Israeli war led the Arab members of the Organization of Petroleum Exporting Countries (OPEC) to impose an embargo on exports of oil to the US for several months. That embargo produced shortages and increases in the price of petroleum products in the US. More important, the success of the embargo suggested to all members of OPEC that they could increase their wealth by withholding supplies from the market and thereby increasing the global price of oil. They began to do so, with a resulting four-fold increase in the price of oil.

The US responded to this sequence of events by retaining price controls on oil and petroleum products when it eliminated economy-wide price controls in 1973. The US imposed oil price controls continuously until 1981. Their effects included long lines at gas stations, implementation of a complicated rationing system, cross-subsidization of imports, increased dependence on imported oil, an increased global price of oil, and lots of work for lawyers. ${ }^{5}$ In 1981, President Reagan deregulated the price of oil and petroleum products. ${ }^{6}$ With cross-subsidies of imports eliminated, the price of oil declined

\footnotetext{
${ }^{1}$ Lyle T. Alverson Professor of Law, George Washington University. I benefited greatly from comments I received on an earlier version of this essay from Rob Glicksman and the participants in the George Washington University works in progress group.

${ }^{2}$ Executive Order 11615, 36 Fed. Reg. 15727 (1971).

38 Fed. Reg. 22536 (1973).

${ }^{4}$ For detailed discussion of the history of regulation of crude oil and petroleum products, see Federal Energy Administration Regulation, Report of the Presidential Task Force (1977).

${ }^{5}$ For detailed discussion of the effects of price controls on crude oil and petroleum products, see Kenneth Arrow \& Joseph Kalt, Petroleum Price Regulation: Should We Decontrol? (1979).

${ }^{6}$ Executive Order 12287, 46 Fed. Reg. 9909 (1981).
} 
significantly. ${ }^{7}$ The oil market has performed well since, and OPEC has little power to increase price artificially by withholding supplies today.

\section{B. Natural Gas-1960 to 2011}

In 1954, a five-Justice majority of the Supreme Court held that the Federal Power Commission (FPC) was required to regulate the wellhead price of natural gas. ${ }^{8} \mathrm{FPC}$ began to impose price controls in the $1960 \mathrm{~s} .{ }^{9}$ By the late $1960 \mathrm{~s}$, air quality rules had increased demand for gas by encouraging switching from coal to oil or gas, and price controls had reduced the supply of gas. The result was a shortage that grew through the 1970s. ${ }^{10}$ The effects of the price controls and the shortage included millions of people out of work due to factory closings, cross-subsidization of imports, an increased global price of gas, implementation of a complicated rationing system, and lots of work for lawyers.

Congress responded by enacting the Natural Gas Policy Act of $1978^{11}$ (NGPA) a statute that divided gas supplies into 23 categories, each subject to a different price ceiling. NGPA created a combination of conditions that most economists previously believed to be impossible - a surplus of gas combined with above market prices for many types of gas. ${ }^{12}$ NGPA also created a situation in which the artificially low regulated price of "old" domestic gas cross-subsidized "high cost gas" and imported gas. Gas in those categories sold for prices two to four times the market price of gas.

Beginning in 1985, the Federal Energy Regulatory Commission (FERC), FPC's successor, issued a series of orders in which it: (1) deintegrated the gas market vertically, separating the natural monopoly functions from the structurally competitive functions; (2) subjected the structurally competitive wholesale gas market to unregulated competition; and, (3) imposed a common carrier form of regulation on the natural monopoly gas transportation function. ${ }^{13}$ With competition in place and cross-subsidies eliminated, the price of gas declined significantly. ${ }^{14}$ The gas market has performed well since.

Over the period 2007-2011, gas producers have combined two traditional practices - horizontal drilling and hydraulic fracturing of shale formations--with excellent results. The supply of gas has increased significantly, with a large resulting decrease in price. ${ }^{15}$ Gas is now less than half the price of oil. ${ }^{16}$ Concern that some chemicals used in hydraulic fracturing are having adverse effects on water quality has resulted in pressure

\footnotetext{
${ }^{7}$ For a detailed description of the history of oil prices, see WTRG Economics, Oil Price History and Analysis website last visited on August 20, 2010.

${ }^{8}$ Phillips Petroleum v. Wisconsin, 347 U.S. 672(1954).

${ }^{9}$ Richard Pierce, Reconstituting the Natural Gas Industry from Wellhead to Burnertip, 9 En. L. J. 1 (1988).

${ }^{10}$ For detailed descriptions of the effects of controls on the wellhead price of gas, see Richard Pierce, Reconsidering the Roles of Regulation and Competition on the Natural Gas Industry, 97 Harv. L. Rev. 345 (1983); Richard Pierce, Natural Gas Regulation, Deregulation, and Contracts, 68 Va. L. Rev. 63 (1982).

${ }^{11}$ Pub. L. No. 95-621, 92 Stat. 3351.

${ }^{12}$ For a detailed description of the effects of NGPA, see Pierce, supra. note 9, at 11-18.

${ }^{13}$ FERC Order 436, 50 Fed. Reg. 42408 (1985); FERC Order 636, 57 Fed. Reg. 13267 (1992).

${ }^{14}$ Richard Pierce, The State of the Transition to Competitive Markets in Natural Gas and Electricity, 15 En. L. J. 323 (1994).

${ }^{15}$ Gideon Rachman, Shale Gas Will Change the World, Financial Times (May 24, 2010).

${ }^{16}$ As of August 13, 2010, the price of gas in the U.S. was $\$ 4.49 / \mathrm{MMBtu}$, while the price of crude oil in the U.S. was \$13.66/MMBtu. Natural Gas Week 7 (Aug. 16,2010).
} 
to increase regulation of hydraulic fracturing, however. ${ }^{17}$ It seems clear that regulation will (and should) increase to some uncertain extent with some uncertain resulting increase in cost and, hence, in the price of gas.

\section{Electricity-1960-2011}

Air quality rules implemented in the 1960s encouraged utilities to install expensive pollution control technologies, to switch from coal to gas, and to begin construction of 200 nuclear generating plants. Economy-wide inflation combined with fuel switching and pollution controls to increase significantly the cost of generating electricity. $^{18}$

The oil and gas shortages of the 1970s and a desire to achieve energy independence induced Congress to enact two statutes in 1978. The Powerplant and Industrial Fuel Use Act (PIFUA) ${ }^{19}$ required utilities and industrial consumers to switch from oil and gas to coal, and prohibited electric utilities from constructing new generating plants that were designed to burn oil or gas. ${ }^{20}$ Congress repealed PIFUA in $1987 .{ }^{21}$ By then it was a counterproductive anachronism. The government-created shortages of oil and gas that had inspired enactment of the statute were long gone, ${ }^{22}$ and it seemed silly to require utilities to rely exclusively on the dirtiest fuel, coal, when they had access to abundant, clean, and inexpensive natural gas.

The second statute Congress enacted in 1978 was the Public Utility Regulatory Policies Act (PURPA). ${ }^{23}$ It encouraged utilities to buy electricity from non-utility generators (NUGS) at above market prices if the NUG used specified preferred technologies that included cogeneration and low head hydro, and it encouraged utilities to use customer funds to make purchases, such as insulation, high efficiency light bulbs, and high efficiency appliances, that were designed to increase their customers' energy efficiency. ${ }^{24}$ Some states, primarily California and the northeastern states, required utilities to enter into long-term contracts to purchase large quantities of electricity from NUGs at prices far above market and rewarded utilities for using their customer's money to make large energy efficiency purchases on behalf of their customers. ${ }^{25}$

The unit price of electricity increased significantly as a result of: (1) economywide inflation; (2) higher costs of fuel and pollution controls; (3) higher than expected costs of constructing nuclear generating plants; (4) methods of regulation used to reflect

\footnotetext{
${ }^{17}$ David Biello, What the Frac? Natural Gas from Subterranean Shale Promises U.S. Energy Independence-with Environmental Costs, Scientific American (March 30, 2010).

${ }^{18}$ Paul Joskow, Inflation and Environmental Concern: Structural Change in the Process of Public Utility

Price Regulation, 17 J. L. \& Econ. 291 (1974).

${ }^{19}$ Pub. L. No. 95-620, 92 Stat. 3289.

${ }^{20}$ For a description of PIFUA, see Pierce, Introduction: Symposium on the Powerplant and Industrial Fuel Use Act of 1978, 29 Kansas L. Rev. 297 (1981).

${ }^{21}$ Energy Information Administration (EIA), Petroleum Chronology of Events 1970-2000 (2002).

${ }^{22}$ Text at notes $1-17$ supra.

${ }^{23}$ Pub. L. No. 95-617, 92 Stat. 3117.

${ }^{24}$ For a description of PURPA, see John Miller, Conscripting State Regulatory Authorities in a Federal Electric Rate Regulatory Regime: A Goal of PURPA Partially Realized, 4 En. L. J. 77 (1983).

${ }^{25}$ Bernard Black \& Richard Pierce, The Choice Between Markets and Central Planning in Regulating the U.S. Electricity Market, 93 Colum. L. Rev. 1339, 1347-48, 1354-89 (1993); Donald Marron, What Does Utility-Subsidized Energy Efficiency Really Cost? Science (Apr. 16, 1993).
} 
the cost of new plants in prices that overstated the cost of those plants; and, (5) a decline in demand caused partly by the increased price of electricity and partly by an economic downturn. ${ }^{26}$ The price of electricity increased most in the states that required utilities to buy a lot of electricity from NUGs at above market prices and that rewarded utilities that used large quantities of their customers' money to make efficiency purchases on their behalf. The price of electricity was almost twice as high in those states as in the states that did not take those actions. ${ }^{27}$

The increased price of electricity produced a consumer backlash that was particularly strong in the states with the highest electricity prices. State regulators used a variety of regulatory doctrines to disallow over 100 billion dollars in investments in cancelled or completed nuclear generating plants. ${ }^{28} 100$ plants were completed, while another 100 partially completed plants were cancelled. No utility has been willing to invest in a new nuclear generating plant since the investment disallowances of the 1980s.

The large increases in the price of electricity also provided the impetus to attempt to restructure the electricity market in a manner similar to the successful restructuring of the gas market in the $1980 \mathrm{~s}$ - vertical deintegration of structurally-competitive functions from monopoly functions, imposition of deregulated competition on the structurallycompetitive wholesale market, and imposition of common carrier type regulation on the monopolistic transmission function. ${ }^{29}$ FERC initiated such a restructuring effort in $1996 .^{30}$

After years of halting progress, FERC abandoned its attempt to restructure the electricity market. The failure of that restructuring effort was attributable to many factors, including: (1) inadequate FERC jurisdiction; (2) the fragmented corporate structure of the utility industry; (3) resistance from some states that wanted to retain complete control over their utilities and from some utilities that did not want to confront competition; (4) low short term price elasticity of demand coupled with inability to store electricity; (5) serious errors made by FERC and by many states; (6) the combination of extraordinarily high prices and intermittent blackouts experienced in California in 2000-2001; and, (7) the 2001 scandal involving the misconduct and ultimate demise of Enron, the largest participant in the nascent competitive electricity market. ${ }^{31}$

\section{THE PRESENT AND FUTURE}

At present, we are focused primarily on use of energy regulation to pursue two goals - energy independence and mitigation of global warming. We are relying mainly on

\footnotetext{
${ }^{26}$ Richard Pierce, Public Utility Regulatory Takings: Should the Judiciary Attempt to Police the Political Institutions? 77 Geo. L. J. 2031, 2047-52 (1989).

${ }^{27}$ Thus, for instance, in 1993, the average price of electricity was 9.69 cents in California, 10.72 cents in New York, and 9.98 cents in Massachusetts, but it was only 5.22 cents in Tennessee, 4.32 cents in Kentucky, and 6.23 cents in Virginia. EIA Electric Power Annual 2008 Average Price by State (2010).

${ }^{28}$ Richard Pierce, The Regulatory Treatment of Mistakes in Retrospect: Cancelled Plants and Excess Capacity, 132 U. Penn. L. Rev. 497 (1984).

${ }^{29}$ Richard Pierce, Using the Gas Industry as a Guide to Reconstituting the Electricity Industry, 13 Res. L \& Econ. 7 (1991).

${ }^{30}$ FERC Order 888 (1996).

${ }^{31}$ Richard Pierce, Completing the Process of Restructuring the Electricity Market, 40 Wake Forest L. Rev. 451, 479-93 (2005).
} 
three tools to pursue those goals - subsidies for domestic carbon-free sources of energy, mandates to electric utilities to increase the per cent of total electricity they generate from carbon-free fuels, and novel uses of the Clean Air Act (CAA).

I see two potential future courses of action - continuation of the status quo and substitution of a large carbon tax for the tools we are now attempting to use. Continuation of the status quo will produce a lot of work for lawyers but poor results for the nation and the world. By contrast, we can maximize the efficacy and efficiency of our efforts if we drop one of our goals - energy independence - and substitute a large carbon tax for the expensive and ineffective tools we are now using in an effort to mitigate global warming.

\section{A. We Should Pursue Only the Goal of Mitigation of Global Warming}

It makes no sense to pursue energy independence as a goal. ${ }^{32}$ Any effective effort to replace all foreign sources of energy with domestic sources would cost trillions of dollars, with little, if any beneficial effects. We are dependent on foreign sources of many important goods. There is no more reason to be concerned about our dependence on foreign sources of energy than to be concerned about our dependence on foreign sources of myriad other important resources.

Lithium is a particularly good example of a resource that is critical to the nation's future and that is, or should be, of greater concern than energy. ${ }^{33}$ Lithium is critical to any effort to manufacture efficient batteries. That, in turn, is critical to our ability to improve the efficiency with which we generate and consume electricity. The US produces only a tiny fraction of the lithium we use. Most of the world's lithium supply is in Bolivia ${ }^{34}$ - a country with an unstable anti-american government and an economy based primarily on cocaine. ${ }^{35}$ By contrast, the largest sources of US energy imports by far are our neighbors, Canada and Mexico, and we are much less dependent on foreign sources of energy than on foreign sources of lithium. ${ }^{36}$

Some people maintain that we could reduce threats to our national security and/or our level of defense spending if we attained energy independence. There is no evidence to support that widely held view, and it is inconsistent with a quick survey of the major threats that now concern us. We import no energy from the any of the five countries that are of greatest concern to us today--North Korea, Afghanistan, Pakistan, Iran, or China. Indeed, four of the five are themselves dependent on foreign sources of energy, and even Iran must import large quantities of gasoline every year. Reducing our dependence on Canada and Mexico as our primary suppliers of energy would have no effect whatsoever on the potential threats to our national security posed by North Korea, Afghanistan, Pakistan, Iran, or China or on our need to devote large sums to national defense.

\footnotetext{
${ }^{32}$ For detailed explanations of the expense and futility of pursuing the goal of energy independence, see Richard Pierce, Energy Independence and Global Warming, 37 Env. L. 595 (2007); Richard Pierce, Déjà Vu All Over Again-The Return of Project Independence and Rate-Payer Funded DSM, 16 Elec. J. 77 (Mar. 2003).

${ }^{33}$ For a detailed analysis of the importance of lithium and its supply and demand, see Dundee Capital Markets, Lithium Supply and Demand (2009).

${ }^{34}$ Id. at 17.

${ }^{35}$ For a detailed description of Bolivia, see U.S. Department of State, Background Note: Bolivia (May 13, 2010).

${ }^{36}$ EIA, Imports by Country of Origin (2010).
} 
By contrast, there is overwhelming evidence that global warming will have catastrophic effects, including the death of millions of people and the displacement of hundreds of millions of people, primarily in impoverished areas like central Africa, central India, Bangladesh and coastal Indonesia. ${ }^{37}$ There is also persuasive evidence that global warming can be mitigated by reducing global emissions of green house gases (ghg), including carbon dioxide (CO2), the most ubiquitous ghg. We should continue to embrace mitigation of global warming as an important goal of energy policy.

We can simplify greatly our choice of means to pursue our goals if we drop pursuit of the ill-conceived goal of energy independence and pursue only the goal of mitigation of global warming. As long as we continue to attempt to pursue both goals simultaneously, we will be forced to make tradeoffs that sacrifice one goal to further the other. Thus, for instance, President Carter's expensive and ill-fated attempt to obtain energy independence relied heavily on maximum substitution of coal for oil and gas. ${ }^{38}$ That is a terrible policy from a global warming perspective. Use of coal results in twice as much emissions of $\mathrm{CO} 2$ as use of natural gas and about fifty per cent more emissions than use of oil. Our present policy of providing massive subsidies for use of corn-based ethanol to replace gasoline is even worse from a global warming perspective. Substitution of corn-based ethanol for gasoline induces increases in deforestation to create land that can be used to cultivate corn and other food crops. ${ }^{39}$ When the effects of those land use changes are added to the $\mathrm{CO} 2$ emissions that result from the process of growing corn and converting it into ethanol, ${ }^{40}$ substituting corn-based ethanol for gasoline has effects on global warming that are even worse than the effects of substituting coal for petroleum products.

\section{B. We Should Replace Our Present Tools With a Carbon Tax}

Once we focus on the single goal of mitigation of global warming, we can identify and implement ways of taking the most important step to further that goalreduction of $\mathrm{CO} 2$ emissions by at least $80 \%$ by 2050 . The present mix of tools we are using to further that goal are expensive, ineffective, and unsustainable. The Supreme Court has provided the foundation for EPA to use the CAA to reduce CO2 emissions, ${ }^{41}$ and the Obama Administration has taken a few modest steps in that direction, ${ }^{42}$ but there is a broad consensus that CAA is poorly designed to reduce $\mathrm{CO} 2$ emissions. In the context of the other pollutants EPA has regulated, it was possible to install pollution control devices that reduced emissions produced by use of hydrocarbons significantly while continuing to consume the fuels. That is not an option in the case of CO2. It is an

\footnotetext{
${ }^{37}$ The United Nations has collected a large body of publications that analyze the causes and consequences of global warming on its website at United Nations Environmental Programmes: Climate Change, last visited August 24, 2010).

${ }^{38}$ Text at notes 18-23, supra.

${ }^{39}$ Timothy Searchinger et al, Use of U.S. Croplands for Biofuels Increases Greenhouse Gases Through Emissions from Land-Use Change, 319 Science 1238 (2008).

${ }^{40}$ For analysis of those effects of corn-based ethanol, see Congressional Budget Office, Using Biofuel Tax Credits to Achieve Energy and Environmental Policy Goals (2010).

${ }^{41}$ Massachusetts v. EPA, 549 U.S. 497 (2007).

${ }^{42}$ For a description of the steps EPA has taken to date, see Robert Glicksman, Environmental Protection: Law and Policy ___ (6 $6^{\text {th }}$ ed. 2011).
} 
inevitable by product of the process of using hydrocarbons. EPA can reduce $\mathrm{CO} 2$ emissions only by reducing use of hydrocarbons. It is not clear how EPA could accomplish that result. The CAA is not designed to accomplish a result of that type.

Subsidies for carbon-free domestic fuels are extremely expensive, largely ineffective, and ultimately unsustainable. The subsidies needed to induce enough substitution of carbon-free fuels to reduce $\mathrm{CO} 2$ emissions by 80 per cent are enormous. Thus, for instance, since energy from windmills is almost twice as expensive as energy from coal or gas, wind farms would have to be assured of subsidies equal to the current price of coal or gas, while producers of solar energy would have to be assured of subsidies equal to three to four times the current price of coal or gas in order to induce large scale switching to carbon-free fuels. ${ }^{43} \mathrm{We}$ simply cannot afford carbon-free fuel subsidies of that magnitude.

Mandates to electric utilities to add enough carbon-free generation to mitigate global warming would be equally expensive, but the cost would be borne by consumers. The average price of electricity would increase significantly if utilities engaged in the massive fuel switching needed to reduce $\mathrm{CO} 2$ emissions by 80 per cent. Of course, consumers would revolt long before mandates could accomplish that result. More modest increases in the price of electricity spawned a consumer revolt in the 1970s and 1980s. ${ }^{44}$

There has long been a broad consensus that the massive reductions in $\mathrm{CO} 2$ emissions needed to mitigate global warming can be attained through only one of two means - a global cap and trade system or a large global carbon tax. ${ }^{45}$ The failure of the Copenhagen meeting has left even many of the strongest proponents of a cap and trade system in despair. ${ }^{46}$ It seems highly unlikely that an effective global cap and trade system can be designed and implemented. That leaves a large carbon tax as the only potentially viable means of mitigating global warming.

Given the present political climate, it is hard to imagine the US adopting a large carbon tax. Democrats are unwilling to increase any taxes on people who earn less than $\$ 250,000$ per year, while Republicans are unwilling to increase any taxes on anyone. ${ }^{47}$ That aspect of the political environment must change in the near future, however, if the US is to avoid the fate of Greece. Unless we make major changes in fiscal policy, we will experience large deficits for the indefinite future. ${ }^{48}$ Deficits of that magnitude are unsustainable. ${ }^{49}$ At some point in the near future, we must reduce spending and increase taxes.

A carbon tax is superior to an increase in income taxes or a value-added tax-the only alternatives to a carbon tax that offer the prospect of increasing revenues to the point

\footnotetext{
${ }^{43}$ These cost estimates and all others in this essay are from EIA, 2016 Levelized Cost of New Generation Resources from the Annual Energy Outlook 2010.

${ }^{44}$ Text at notes 23-29 supra.

${ }^{45}$ Richard Pierce, Energy Independence and Global Warming, 37 Env. L. 595, 600-601.

${ }^{46}$ See, e.g, Robert Stavins, Another Copenhagen Outcome: Serious Questions About the Best Institutional Path Forward, Belfer Center, John F. Kennedy School, Harvard University (2010); Sustainability Institute, C-Roads Analysis of Final Copenhagen Accord, MIT Sloan School of Management (2009);

${ }^{47}$ Editorial, A Real Debate on Taxes, New York Times (August 24, 2010).

${ }^{48}$ The Obama Administration proposes a budget deficit of between 533 billion dolars and over one trillion dollars for the indefinite future. Office of Management and Budget, A New Era of Responsibility 119 (2009).

${ }^{49}$ International Monetary Fund, Fiscal Monitor: Navigating the Fiscal Challenges Ahead (2010).
} 
at which our budget deficit will be tolerable. Taxes discourage the taxed activity. Thus, income taxes discourage work, while a value added tax discourages purchases of all types of goods and services. By contrast, a carbon tax discourages only what we need to discourage to mitigate global warming - emissions of $\mathrm{CO} 2$.

A carbon tax is superior to subsidies for carbon-free energy sources in two important respects. First, it has the opposite effect on the budget deficit. While subsidies increase the deficit, a carbon tax would decrease the deficit. Second, it is much easier to design and to implement. To be effective, a carbon tax need only deter consumption of hydrocarbons. Consumers are left with complete discretion with respect to the ways in which they reduce their consumption of hydrocarbons, e.g., by increasing the efficiency of their use of energy or by substituting for hydrocarbons some mix of carbon-free fuels like wind power, solar power, or nuclear power. It is important to give consumers that flexibility, both because the alternatives will be more or less attractive to different consumers in a variety of different situations and because we cannot predict which of the alternatives to hydrocarbons will become more attractive in the future as a result of technological breakthroughs. By contrast, subsidies must be set at levels that are adequate to encourage optimal substitution of each subsidized alternative. By definition, they are always too high or too low, both because of the varying circumstances of consumers and because of the dynamic and unpredictable pace of technological progress.

\section{Will a Carbon Tax Be Effective?}

I am confident that a large carbon tax is the best policy the US can implement in an effort to mitigate global warming. I am less confident, however, that a carbon tax implemented by the US will be effective in mitigating global warming, given the daunting nature of the task. The climate experts tell us that we must reduce global $\mathrm{CO} 2$ emissions by $80 \%$ by 2050 . I am skeptical that there is anything the US can do that can accomplish that result. My skepticism has two sources - the likely behavior of some other countries and the extreme difficulty of meeting this goal even in the US.

It is reasonable to assume that most other developed countries, e.g., the members of the EU and Japan, would join the US in an effort to reduce their $\mathrm{CO} 2$ emissions by $80 \%$, but it is not realistic to make such an assumption with respect to most developing countries, e.g., China, India, and Russia. If the developed countries reduce their $\mathrm{CO} 2$ emissions by reducing their consumption of hydrocarbons, developing countries are likely to increase their emissions by increasing their consumption of hydrocarbons. Any significant reduction in the quantity of hydrocarbons consumed in developed countries will reduce the global price of hydrocarbons. That, in turn, will yield increased consumption of hydrocarbons in the developing countries that already account for almost all of the increases in global $\mathrm{CO} 2$ emissions in recent years.

The extent to which increased hydrocarbon consumption and increased $\mathrm{CO} 2$ emissions in developing countries will offset decreased hydrocarbon consumption and decreased $\mathrm{CO} 2$ emissions in develop countries will depend on the price elasticity of demand for hydrocarbons in developing countries over the next forty years. Estimates of that metric range from $29 \%$ to $70 \%,{ }^{50}$ so increased emissions in developing countries will

\footnotetext{
${ }^{50}$ Steven Stoft, Renewable Fuel and the Global Rebound Effect, Global Energy Policy Center Research Paper No. 10-06 (2010).
} 
offset about one-half of the decreased emissions in developed countries unless developing countries impose meaningful limits on their emissions. That is why efforts must continue to implement an international agreement that imposes meaningful limits of some type on the emissions of ghgs in developing countries. ${ }^{51}$ Without such limits, nothing the US does is likely to be effective in mitigating global warming.

Even a US effort to reduce our $\mathrm{CO} 2$ emissions by $80 \%$ would be extremely expensive and time-consuming. It also would produce adverse effects on the environment of uncertain magnitude. To illustrate the difficulty of the task, I will describe briefly each of the potential steps the US might take to reduce $\mathrm{CO} 2$ emissions in the electricity sector by $80 \%$ and a few of the obstacles to implementation of each of those steps.

The electricity sector accounts for forty per cent of US emissions of $\mathrm{CO} 2{ }^{52}$ The present composition of our sources of electricity are: $46 \%$ coal; $21 \%$ gas; $20 \%$ nuclear; $2 \%$ oil; $7 \%$ hydropower, and $4 \%$ other renewable. ${ }^{53}$ Since coal consumption produces twice as much $\mathrm{CO} 2$ emissions as gas consumption, we would need to eliminate completely all emissions attributable to coal to reach the goal of an $80 \%$ reduction in $\mathrm{CO} 2$ emissions in the electricity sector. That statistic illustrates a major political obstacle. Coal is mined throughout Appalachia and the Powder River Basin. Any effort to eliminate coal mining through any means will face strong opposition from the many members of the House and Senate who represent states and districts in which coal accounts for a significant part of the economy. There are many paths we can take to move toward elimination of $\mathrm{CO} 2$ emissions from use of coal in generating plants, but there are many obstacles on each of those paths. I will begin by describing the generic obstacles to the kinds of changes we need to make to reduce $\mathrm{CO} 2$ emissions from electricity generation by $80 \%$.

First, all carbon-free sources of electricity are more expensive than coal or gas. ${ }^{54}$ Thus, inducing consumers to switch sources will require either large subsidies or a large carbon tax. Second, electricity cannot be stored economically. That is important because some of the carbon-free sources of electricity are unpredictable in their availability. Thus, for instance, wind power is available only when the wind velocity falls within a particular range, and solar power is available only when the sun shines. This characteristic would be much less important if we could generate electricity in one period, store it economically, and consume it in another period. Since electricity cannot be stored economically, we can add only a modest amount of wind or solar energy to the grid without significantly impairing reliability. ${ }^{55}$ Third, the US has traditionally relied on state and local governments to regulate the most important activities that are needed to generate, transmit, and distribute electricity. Some state and local governments are not likely to share the national government's interests in taking the actions needed to mitigate global warming, and even those that do are likely to have divergent preferences with respect to the best means to further that goal. No national plan to mitigate global warming can

\footnotetext{
${ }^{51}$ Sheila Olmstead and Robert Stavins, Three Key Elements of Post-2012 International Climate Change Architecture, Harvard Kennedy School Working Paper No. RWP10-030 (2010).

${ }^{52}$ EPA, Inventory of Greenhouse Gas Emissions and Sinks (Apr. 2010).

${ }^{53}$ EIA, 2010 Net Generation by Energy Source (August 11, 2010).

${ }^{54}$ EIA, note 43 , supra.

${ }^{55}$ For a comprehensive discussion of the relationship between various carbon-free energy sources and reliability of electricity service, see North American Reliability Council, Reliability Impacts of Climate Change Initiatives (July 2010).
} 
succeed if California and Oklahoma are free to adopt different policies with respect to the actions needed to mitigate global warming. ${ }^{56}$ Fourth, increased reliance on carbon-free sources like wind or solar will require large additions to our transmission grid. Most such additions provoke strong opposition on aesthetic grounds, ${ }^{57}$ and there is an ongoing controversy over the manner in which such expansions should be financed. ${ }^{58}$ Fifth, the US is extremely litigious. Most of the projects needed to mitigate global warming will provoke opposition at regulatory agencies and in courts. The resulting litigation will slow the rate at which we can achieve the mitigation goal and increase the cost of achieving that goal.

\section{a. Conservation}

Turning to particular steps that can be taken to mitigate global warming, I will begin with the step most people believe to be the most promising conservation/increased efficiency of use. Price is the most reliable and effective means of encouraging conservation and increased efficiency. If consumers confront electricity prices that reflect accurately the cost of electricity, including external costs like those attributable to global warming, they will decrease their consumption of electricity and increase the efficiency with which they use electricity. A large carbon tax would move the price of electricity in the right direction, but it is not enough.

Demand for electricity varies greatly over time. Since electricity cannot be stored economically, that widely varying demand must be met with contemporaneous variations in supply. The cost of supplying a kilowatt hour (kwh) of electricity to a particular location can vary by as much as a factor of twenty to one depending on the time when the electricity is supplied. Yet, most consumers pay a price for each kwh that does not vary as the cost of a kwh goes up or down. We can encourage consumers to engage in optimal efforts at conservation and efficiency enhancement only by changing the methods used to bill consumers. To accomplish that goal, we must install smart meters for all consumers. Smart meters allow consumers and utilities to observe the constantly changing cost of electricity and to measure consumption at each cost level. Smart meters will have no effect, however, unless we also change the method of billing all consumers so that the price they pay for each kwh varies greatly depending on the constantly changing cost of meeting their demand for electricity.

The federal government is attempting to implement a smart grid that would include smart meters and new billing methods. It lacks the power to make the needed changes, however. Both the decision whether to authorize a utility to install smart meters and the decision to change the method of billing consumers is subject to state regulation. The federal efforts to implement a smart grid have made little progress because many consumer advocacy groups and state regulators have objected on a wide variety of

\footnotetext{
${ }^{56}$ For an excellent analysis that demonstrates the problems created by state-based attempts to mitigate global warming, see Lincoln Davies, Power Forward: The argument for a National RPS, 42 Conn. L. Rev. 1339 (2010).

${ }^{57}$ Richard Pierce, Environmental Regulation, Energy, and Market Entry, 15 Duke Env. L. \& Pol. Forum 167, 176-183 (2005).

${ }^{58}$ FERC wants to spread the cost of expanding transmission capacity across all consumers in a region, but the Seventh Circuit has rejected that approach. Illinois Commerce Commission v. FERC, 576 F.3d 470 ( $7^{\text {th }}$ Cir. 2009).
} 
grounds. ${ }^{59}$ Unless consumer advocacy groups or state regulators change their attitudes dramatically or Congress gives the federal government the power to require installation of smart meters and changes in billing methods and the federal government exercises that power, the highly touted attempt to install a smart grid will go nowhere.

Some people believe that price provides an inadequate incentive for consumers to conserve because of various imperfections in the market. ${ }^{60}$ In order to overcome those imperfections, they urge adoption of state regulatory systems that reward utilities for using their customers' funds to make large payments for energy conservation purposes on behalf of their customers. Under a system of this type, a utility would pay for additional home insulation, high efficiency light bulbs, and high efficiency appliances, and add the cost of those acquisitions, plus a reward for their conservation-enhancing efforts, to their customers' bills.

Several states implemented regulatory systems of this type in the late 1970s and early 1980 s with unfortunate effects. ${ }^{61}$ The new systems replaced one arguable market imperfection with another-utilities that are rewarded for making purchases on behalf of their customers do not have an incentive to insure that the purchases are cost effective. Audits of the customer-funded conservation acquisition programs consistently found that the efficiency enhancing claims for the goods and services purchased by the utilities were overstated. Ultimately, all of the state agencies that authorized programs of that type were forced by consumer backlash to abandon them.

\section{b. Switching to Natural Gas}

We can achieve some part of our global warming mitigation goal by encouraging utilities to switch from coal to gas. At present, gas is available in abundance at about the same price as coal, and it emits only half as much $\mathrm{CO} 2$ as coal per kwh of electricity produced. There are limits on our ability to use switching to gas as a mitigation strategy, however. In the short term, only about ten per cent of generating capacity that uses coal can switch to gas. Over a longer period, of course, we could substitute gas for all of our present coal capacity. It is highly likely, however, that the price of gas will increase, perhaps significantly, as a result of increased regulation of hydraulic fracturing and increased demand attributable to fuel switching. Moreover, even a complete replacement of coal with gas would decrease emissions of $\mathrm{CO} 2$ attributable to electricity generation by only about $45 \%$--far short of the $80 \%$ needed to mitigate global warming.

\section{c. Switching to Nuclear}

We could pursue a strategy of switching from coal to nuclear. The obstacles to success in pursuing that strategy include: nuclear energy is about $20 \%$ more expensive than coal or gas; ${ }^{62}$ nuclear is controversial with the public; we have made no progress in solving the permanent nuclear waste disposal problem; nuclear generating plants are

\footnotetext{
${ }^{59}$ For an overview of this controversy, see Michael Burr, Summer of Discontent: Smart Grid Planners Feel the Heat, Pub. Util. Fort. 4 (Aug. 2010).

${ }^{60}$ Black \& Pierce, note 25 supra., at 1362-78.

${ }^{61}$ Marron, note 25 supra.

${ }^{62}$ EIA, note 43 supra.
} 
difficult to finance; and prospective investors remember the $\$ 100$ billion dollars in losses investors in nuclear plants suffered in the 1980s. ${ }^{63}$

\section{d. Switching to Hydro}

We could pursue a strategy of switching from coal to hydro power. The obstacles to success in pursuing that strategy include: hydro is about $20 \%$ more expensive than coal or gas; ${ }^{64}$ the US has limited untapped hydro potential; and hydro has become unpopular with the public because of the effects of dams on fisheries resources.

\section{e. Switching to Geothermal}

We could pursue a strategy of switching from coal to geothermal. The obstacles to success in pursuing that strategy include: geothermal is about $16 \%$ more expensive than coal or gas; ${ }^{65}$ there are limited viable sites and many are in environmentally sensitive areas such as Yellowstone National Park; geothermal induces category 3 plus earthquakes; earthquakes closed the large geothermal project in Basel, ${ }^{66}$ resulted in the criminal indictment of the Basel project manager, forced cancellation of a large project in California, ${ }^{67}$ and created serious NIMBY problems for any potential geothermal project in the US.

\section{F. Switching to Wind}

We could pursue a strategy of switching from coal to wind. The obstacles to success in pursuing that strategy include: wind is $50-90 \%$ more expensive than coal or gas; wind farms kill large numbers of birds and bats; ${ }^{68}$ wind farms raise serious issues under the Endangered Species Act; ${ }^{69}$ windmills are extremely noisy; wind farms are aesthetically controversial; windmills are low load factor; it takes about 1000 windmills to equal the output of one standard-sized generator; wind power is unreliable because its availability depends on wind velocity; and because of its unreliability and low load factor, wind power requires construction of a disproportionately large number of new transmission lines.

\section{G. Switching to Solar}

We could pursue a strategy of switching from coal to one of two forms of solar energy - central station thermal or decentralized photovoltaic. The obstacles to success in

\footnotetext{
${ }^{63}$ Text at notes 27-29 supra.

${ }^{64}$ EIA, note 43 supra.

${ }^{65}$ EIA, note 43 supra.

${ }^{66}$ Adam Gabatt, Swiss Geothermal Power Plan Abandoned After Quakes Hit Basel, Guardian (December 15, 2009).

${ }^{67}$ James Glanz, Geothermal Project in California Is Shut Down, New York Times (Dec. 11, 2009).

${ }^{68}$ Robert Bryce, Windmills Are Killing Our Birds, Wall Street Journal (Sep. 7, 2009); Catherine Brahic, Wind Turbine Makes Bat Lungs Explode, New Scientist (Aug. 25, 2008).

${ }^{69}$ A federal judge ordered the shut down of a large wind farm because it was killing endangered bats. Animal Welfare League v. Beech Ridge Energy, 657 F. Supp.2d 540 (D. Md. 2009).
} 
pursuing a solar thermal policy include: solar thermal is about $160 \%$ more expensive than coal or gas; ${ }^{70}$ it is unreliable because it is available only when the sun shines; it requires new transmission lines; and it requires a large amount of land that is rendered useless for any other purpose. The obstacles to success in pursuing decentralized photovoltaic include: photovoltaic is about $300 \%$ more expensive than coal or gas ${ }^{71}$ it requires states to approve feed in tariffs to allow solar producers to sell their excess electricity to the grid at generous prices; it is unpopular with many zoning boards and neighborhood associations; ${ }^{72}$ and it is unreliable because it is available only when the sun shines.

\section{F. Switching to Clean Coal}

We could pursue a strategy of switching from coal to "clean coal" by implementing a program of carbon capture and storage (ccs). The obstacles to success in pursuing that strategy include: it has never been done on a large-scale basis; it would increase the cost of generating with coal by about $30 \%{ }^{73}$ it would take decades to construct the required pipeline network and underground storage caverns; safe storage of $\mathrm{CO} 2$ may be more difficult and risky than safe storage of spent nuclear fuel; a $\mathrm{CO} 2$ leak in Cameroon killed 1700 people in $1986 ;{ }^{74}$ public awareness of the risks of CO2 storage will cause major NIMBY problems; and no one will embark on such a project without federal legislation that limits the project sponsor's liability in the event of a catastrophic leak.

\section{CONCLUSION}

I hope that my description of the limited options available to us to reduce $\mathrm{CO} 2$ emissions by $80 \%$ and the formidable obstacles to success in attaining that goal persuade you both that the task is daunting and that a large carbon tax provides the best prospect for success in attaining the goal. A large carbon tax would offset to some extent the difference between the cost of continuing to rely primarily on hydrocarbons to generate electricity and the cost of switching to primary reliance on carbon-free sources of electricity. It also would spur investment in the research and development needed to enhance the efficiency with which we use electricity, reduce the cost of using carbon-free sources, improve the reliability of sources like wind and solar, and develop methods of storing electricity at tolerable cost. Perhaps most important, it would leave producers and consumers free to take advantage of the options that evolve as best for them given the high variability of their circumstances and the uncertain pace of technological progress in taking the steps needed to mitigate global warming.

Our only hope of mitigating global warming lies in major technological breakthroughs. With the economic incentives created by a large carbon tax, we are likely to attain significant improvements in the technology needed to mitigate global warming.

\footnotetext{
${ }^{70}$ EIA, note 43 supra.

${ }^{71}$ EIA, note 43 supra.

${ }^{72}$ Troy Rule, Renewable Energy and the Neighbors, University of Missouri School of Law Legal Studies Research Paper No. 2010-13.

${ }^{73}$ EIA, note 43 supra.

${ }^{74}$ National Geographic, Nature Untamed, Death Fog (Aug. 27, 2010).
} 
It is impossible to predict, however, whether the major advances will take place in the context of conservation/enhanced efficiency, reduced costs and/or increased reliability of specific carbon-free sources, or improved ability to store electricity economically. If we implement a large carbon tax, we do not have to engage in the hazardous process of predicting technological advances. If they take place primarily in the context of solar power, the tax will automatically channel most of our mitigation efforts in that direction. Conversely, if they take place primarily in the context of some other source, such as conservation/efficiency enhancement, cost of storage, wind, geothermal, clean coal, or nuclear, the tax will automatically channel most of our efforts down whatever path has become the most economic route to mitigate global warming. 